\title{
İleri Kademe Bazı Ekmeklik Buğday (Triticum aestivum L.) Genotiplerinin Yağışa Dayalı Şartlarda Tane Verimi ve Bazı Kalite Parametreleri Yönünden Değerlendirilmesi
}

\author{
*Enes YAKIŞIR ${ }^{1} \quad$ Seyfi TANER ${ }^{2} \quad$ Melek BAYRAKTAROĞLU1 ${ }^{1} \quad$ Telat YILDIRIM $^{1}$ \\ Mehmet Ali ÇAYIRÖZ ${ }^{1} \quad$ İbrahim KARA ${ }^{1} \quad$ Musa TÜRKÖZ $^{1} \quad$ Şah İsmail CERIT ${ }^{1}$ \\ Mehmet ŞAHIN ${ }^{1} \quad$ Seydi AYDOĞAN ${ }^{1}$
}

\author{
1Bahri Dağdaş Uluslararası Tarımsal Araştırma Enstitüsü Müdürlüğü, Konya \\ ${ }^{2}$ Aksaray Teknik Bilimler Meslek Yüksekokulu, Aksaray \\ *Sorumlu yazar e-posta (Corresponding author; e-mail): enesyakisir@hotmail.com
}

Öz

Bu araştırma, 2013-2014 yetiştirme döneminde ileri kademe bazı ekmeklik buğday genotiplerinin tane verimi ve bazı kalite parametrelerinin belirlenmesi amacıyla yürütülmüştür. Araştırma materyali; Bahri Dağdaş Uluslararası Tarımsal Araştırma Enstitüsünce yürütülen ıslah çalışmaları kapsamında bölge verim kademesinde yer alan 14 hat ve 6 standart çeşitten oluşmaktadır. Çalışma 9 çevrede (Konya, İçeriçumra, Gözlü, Koçaş, Karaman, İkizce, Malya, Eskişehir, Hamidiye) Tesadüf Blokları Deneme Deseninde 4 tekerrürlü olarak yürütülmüş, kalite parametreleri Konya ve İçeriçumra çevrelerinde 2 tekerrürlü olarak elde edilmiştir. Çalışmada tane verimi (kg/da), bintane ağılığı (g), protein (\%) ve Zeleny sedimentasyon (ml) özellikleri incelenmiştir. Çevre ortalamaları değerlendirildiğinde tane verimi bakımından en yüksek değer $383 \mathrm{~kg} / \mathrm{da}$ ile Malya'dan, en düşük değer 114 kg/da ile Hamidiye'den elde edilmiştir. Çalışmadaki tüm genotipler 9 çevrede tane verimi bakımından değerlendirildiğinde en yüksek değer 269 kg/da ile hat 15 'den elde edilirken en düşük değer $171 \mathrm{~kg} / \mathrm{da}$ ile hat 17 'den elde edilmiştir. Denemede ele alınan kalite parametrelerinden bin dane ağırlığı 27.4-38.2 g arasında, protein oranı \%12.26-14.80 arasında ve Zeleny sedimentasyon 34.7-57.2 ml arasında değişim göstermiştir. İncelenen özellikler bakımından kontrol çeşitler ve diğer hatlardan daha üstün özellik gösteren 1 adet hat, aday çeşit olarak Tohumluk Tescil ve Sertifikasyon Merkez Müdürlüğüne başvurusu yapılmış ve tescil denemelerine aktarıımıştır.

Anahtar Kelimeler: Ekmeklik buğday, verim, kalite

\section{Assessment of Advanced Bread Wheat Genotypes (Triticum aestivum L.) for Yield and Some Quality Traits under Rainfed Conditions}

\begin{abstract}
Research materials are consist of the scope of breeding studies by Bahri Dağdaş International Agricultural Research Institute's 14 lines and 6 varieties from Regional yield trial. Study carried out at 9 environment (Konya, İçericumra, Gözlü, Koçaş, Karaman, İkizce, Malya, Eskişehir \& Hamidiye) with randomized block pattern in 4 replications, quality parameters recieved from Konya \& İçeriçumra environment with 2 replication. The study grain yield $(\mathrm{kg} / \mathrm{ha})$, thousand kernel weight $(\mathrm{g})$, protein $(\%)$ and Zeleny sedimentation $(\mathrm{mL})$ properties were investigated. The highest average grain yield in terms of environmental value as assessed $383 \mathrm{~kg} /$ ha with the Malya; were the lowest, $114 \mathrm{~kg} /$ ha were obtained by the Hamidiye. With regard to grain yield in all 9 genotypes at the study highest value around $269 \mathrm{~kg} /$ ha from the line 15 while the lowest value $171 \mathrm{~kg} /$ ha were obtained from the 17 line. The quality parameters of the experiment discussed in thousand grain weight between $27.4-38.2 \mathrm{~g}, 12.26-14.80 \%$ protein content ranged between and Zeleny sedimentation between 34.7-57.2 $\mathrm{mL}$. When the control varieties and the other lines one line showed superior characteristics and we applied this line as a candidate to Variety Registration and Seed Certification Center and was transferred to registration trials.
\end{abstract}

Keywords: Bread Wheat, yield, quality 
Yakışır ve ark. "Illeri Kademe Bazı Ekmeklik Buğday (Triticum aestivum L.) Genotiplerinin Yağışa Dayalı Şartlarda Tane Verimi ve Bazı Kalite Parametreleri Yönünden Değerlendirilmesi"

\section{Giriş}

slah programları genelde üretici, tüketici ve sanayicinin istekleri doğrultusunda oluşturulmaktadır. Bu amaçla ekmeklik buğdayda tane verimi ve kaliteyi arttırmak için çeşit geliştirme programlarında çeşitli yöntemler kullanılmaktadır. Bu yöntemlerden seleksiyon önemli bir yer tutmaktadır. Uzun yıllar süren ve zahmet gerektiren ıslah çalışmalarında hedefe ulaşmak için üzerinde çalışılan karakterin genetik mekanizmalarının iyi bilinmesi ve buna bağlı olarak uygun genotiplerin seçilmesi gerekmektedir.

Ülkemizde 7.9 milyon ha alanda yaklaşık 20 milyon ton üretimi yapılan buğdayın ekiliş alanının \%84'ünü, üretiminin ise $\% 82$ 'sini ekmeklik buğday oluşturmakta, üretim miktarında yıldan yıla önemli dalgalanmalar görülmektedir. (Anonim, 2014). İnsan beslenmesi açısından son derece önemli olan buğdayın nüfus artışıyla orantılı olarak üretiminin arttırılması gerekmektedir. Buğdayda verim, kullanılan çeşidin genetik yapısı, tohumluk safiyeti ve bölgeye adaptasyonundan önemli oranda etkilenmektedir. Kün ve ark. (1995), buğdayda verimin uygun çeşit ve kaliteli tohumluk ile kuru tarım sisteminde \%30'lara kadar artırılabileceğini bildirmişlerdir. Bu sebeple hedef bölge koşullarında verimi yüksek ve kaliteli çeşitlerin belirlenmesi önemlidir.
Buğday da yüksek tane verimi yanında, amaca uygun kalitenin de göz önünde bulundurulması gerekmektedir. Buğdayın kalitesi genotip $\mathrm{x}$ çevre interaksiyonu etkisinden dolayı çevreden etkilenme oranı da farklı olabilmektedir. Buğday da kalitenin meydana gelmesinde birinci derecede rol oynayan unsur, protein miktarı ve protein kalitesidir (Sade 1997). Buğday ıslah çalışmalarında temel amaç birim alandan elde edilen tane verimini arttırmak ve kaliteyi iyileştirmektir. Zamanla değişen tüketici talepleri ve gıda teknolojisindeki yeni gelişmeler verimli ve kaliteli çeşit geliştirme çalışmalarının önemini ortaya koymaktadır. Bu çalışma Orta Anadolu ve Geçit Bölgelerinin farklı çevrelerinde yağışa dayalı şartlarda ileri kademe bazı ekmeklik buğday genotiplerinin verim ve bazı kalite özellikleri açısından değerlendirilerek yüksek performans gösteren genotiplerin belirlenmesi amacıyla yapılmıştır.

\section{Materyal ve Yöntem}

Bu araştırma, Bahri Dağdaş Uluslararası Tarımsal Araştırma Enstitüsünce yürütülen ekmeklik buğday ıslah çalışmaları kapsamında 2013-2014 yetiştirme sezonunda bölge verim kademesinde yer alan 14 hat ve 6 standart çeşit (Bayraktar 2000, Gerek 79, Karahan 99, Tosunbey, Bezostaja 1, Eraybey) olmak üzere 20 genotipten oluşmaktadır. Denemede kullanılan genotipler Çizelge 1'de verilmiştir

Çizelge 1. Denemede kullanılan genotipler

Table 1. Genotypes used in trial

\begin{tabular}{cl}
$\begin{array}{c}\text { Genotip } \\
\text { No }\end{array}$ & \multicolumn{1}{c}{ Hat/Çeşit } \\
\hline 1 & Bayraktar 2000 (Tarla Bitkileri Merkez Araştırma Enstitüsü) \\
2 & Gerek 79 (Geçit Kuşağı Tarımsal Araştırma Enstitüsü) \\
3 & Karahan 99 (Bahri Dağdaş Uluslararası Tarımsal Araştırma Enstitüsü) \\
4 & Tosunbey (Tarla Bitkileri Merkez Araştırma Enstitüsü) \\
5 & Bezostaja 1 (Mısır Araştırma İstasyonu) \\
6 & Eraybey (Bahri Dağdaş Uluslararası Tarımsal Araştırma Enstitüsü) \\
7 & SOYER02/MERCAN-1 \\
8 & SOYER02/6/NGDA146/4/YMH/TOB//MCD/3/LIRA/5/F130L1.12 \\
9 & ES84-16/BAYRAKTAR2000 \\
10 & MNCH/MO88//2*ALTAY2000 \\
11 & PAVON/2*BAYRAKTAR2000 \\
12 & DWIRNAZ99-2/2*ALTAY2000 \\
13 & DWIRNAZ99-2/2*ALTAY2000 \\
14 & DAĞDAŞ//BOBWHITE\#1/FRENGKANG 15 \\
15 & W0405D/HGF112//W7469C/HCF012/3/MERCAN-2 \\
16 & ZENCiRCi/BACANORA \\
17 & BEZ4/4/LOV10/CD*2//CO//CO/3/SANTACATALINAKENYA2//4-11/5/RPB 8- \\
18 & 68/CHRC/3/BEZ//BEZ/TVR \\
19 & GV/4/D6301/NAI//WRM/3/CNO*3/ CHR/5/ BL2973/6/ LOVRiN6/SAMSUN \\
20 & SERI.1B*2/3/KAUZ*2/BOW//KAUZ/6/YMH/HYS//HYS/TUR3055/3/DGA/4/VPM/MOS/5/TRAP \\
\hline
\end{tabular}


Çalışma 9 çevrede (Konya, İçeriçumra, Gözlü, Koçaş, Karaman, İkizce, Malya, Eskişehir, Hamidiye) Tesadüf Blokları Deneme Deseninde 4 tekerrürlü olarak yürütülmüştür. Deneme parselleri hasatta 5 metre x 6 sıra $(6$ $\mathrm{m}^{2}$ ) olacak şekilde Ekim ayında deneme mibzeri ile ekilmiştir. Ekim ile birlikte dekara $7 \mathrm{~kg}$ olacak şekilde saf $P$ (DAP \%18-46) uygulanmış ve ilkbaharda \%33'lük amonyum nitrat ilavesi ile saf $\mathrm{N}$ miktarı $7 \mathrm{~kg} / \mathrm{da}$ 'a tamamlanmıştır.

Deneme yağışa dayalı şartlarda yürütülmüştür. Genotipler hasat olgunluğuna geldiğinde parsel biçerdöveri ile Temmuz ayında hasat edilmiştir.. Hasat sonrası bin tane ağırlığı, protein oranı ve Zeleny sedimentasyon gibi bazı kalite özellikleri incelenmiş, bin tane ağırlığı AACC 55-10, Zeleny sedimentasyon AACC 5770 'e göre (Anonim 2000), protein oranı ise AOAC 992.23'e göre yapılmıştır (Anonim, 2009). Kalite parametreleri Konya ve İçeriçumra çevrelerinde 2 tekerrürlü olarak değerlendirilmiştir.

Araştırma sonucu elde edilen değerler 'Tesadüf Blokları Deneme Desenine' göre varyans analizine tabi tutulmuş ' $f$ ' testi yapılmak suretiyle farklılıkları tespit edilen uygulamaların ortalama değerleri 'LSD' testine göre gruplandırımıştır. İstatistiki analizde JMP 11.0 paket programı kullanılmıştır. Denemenin yürütüldüğü 2013-2014 yetiştirme sezonunda (Eylül-Haziran) Konya, Gözlü, İkizce, Malya ve Eskişehir çevrelerinden yıllık ve uzun yıllar yağış verileri temin edilmiş olup, sırasıyla 198-299 $\mathrm{mm}$; 237-237 mm; 285-336 mm; 214-273 mm ve $286-327 \mathrm{~mm}$ şeklinde gerçekleşmiştir.

\section{Bulgular ve Tartışma}

Orta Anadolu ve Geçit Bölgesi için yüksek performans gösteren genotipleri belirlemek amacıyla yürütülen bu araştırmada genotipler, tane verimi bakımından değerlendirilmiş, çevrelerin verim ortalamaları ve 9 çevreye ait ortalama verim değerleri ile 'LSD' test grupları Çizelge 2'de verilmiştir.

Çevre faktörlerinden başta ekim zamanı olmak üzere yağışın yıl içindeki dağılımı, minimum ve maksimum sıcaklıklar, besin elementi takviyesi, hastalık ve zararlı mevcudiyeti gibi faktörler verim potansiyelini belirlediği (Mut ve ark. 2005), bunun yanında buğdayda verim açısından vejetasyon döneminde düşen yağış miktarından çok, yağışın yetişme döneminde dağılımının önemli olduğunu vurgulanmaktadır (Çetin ve ark. 1999). Yapılan çalışmada çevreler ve genotipler arasındaki fark istatistiki olarak $P<0.01$, çevre $x$ genotip interaksiyonu ise $P<0.05$ seviyesinde önemli olarak tespit edilmiş olup, çevreler tane verimi bakımından değerlendirildiğinde en yüksek değer Malya'dan (383 kg/da), en düşük değer ise Hamidiye'den (114 kg/da) elde edilmiştir. Çalışmada kullanılan genotiplerin ortalama tane verimleri değerlendirildiğinde denemelerin ortalaması $235 \mathrm{~kg} / \mathrm{da}$, standart çeşit ortalaması $245 \mathrm{~kg} / \mathrm{da}$ olarak belirlenmiştir. En yüksek tane verimi $270 \mathrm{~kg} / \mathrm{da}$ ile hat 15 'den, en düşük ise $172 \mathrm{~kg} / \mathrm{da}$ ile hat17'den elde edilmiştir. Genotip $\times$ çevre interaksiyonu bakımından ise en yüksek değer; Malya'da Bayraktar 2000 (470 kg/da) çeşidinden, en düşük Gözlü'de hat17 (70 kg/da) genotipinden elde edilmiştir. Standart çeşitlere ait ortalamadan $(245 \mathrm{~kg} / \mathrm{da})$ daha yüksek tane verimine sahip 4 hat belirlenmiş olup, bunlar sırasıyla hat 15 , hat 20 , hat 8 ve hat 18 (sırasıyla $270 \mathrm{~kg} / \mathrm{da} ; 263$ $\mathrm{kg} / \mathrm{da} ; 258 \mathrm{~kg} / \mathrm{da} ; 252 \mathrm{~kg} / \mathrm{da}$ )'dir. Bu 4 hat içerisinde yer alan hat 15 , standart çeşitler içerisinde en yüksek verime sahip olan Bayraktar 2000 ve Karahan 99 çeşitlerinden (sırasıyla 268 kg/da;265 kg/da) daha yüksek tane verimine ulaşmıştır (Çizelge 2). Nitekim, çalışmada yukarıdaki araştırıcıların verim üzerine iklimin etkilerini bildirdiği gibi, özellikle verimin belirlendiği büyüme ve gelişme dönemlerinde yağışlar mevsim normallerinin altında bir seyir izlemiştir. Ayrıca ekimle birlikte çıkış için yeterli yağış alınamamış, kış aylarına girerken dahi çıkışlar sağlanamamıştır. Ocak ayı ile başlayan kış yağışları ile birlikte de hava ve toprak sıcaklıklarında ki ani sıcaklık düşmesi üniform olmayan çıkışlar ve vejetasyonda gerilemelere neden olmuştur. Verim; bitkinin genetik potansiyeli, çevre faktörleri ve yetiştirme tekniklerinin birlikte etkileri sonucu ortaya çıkmaktadır. Nitekim ıslah çalışmalarında temel amaç verim ve kalite özelliklerinin iyileştirilmesidir. Dünya'da, son 30-35 yılda buğday veriminde sağlanmış olan $\% 100$ 'ük artışın, \%60'ının yüksek verim potansiyeline sahip yeni ıslah çeşitlerinden, $\% 40$ 'ının ise çevre ve kültürel uygulamalardaki gelişmelerin bir yansımasından olduğu kabul edildiği (Roth ve ark. 1984) yargısı, çalışmamızdaki genotiplerin verim farklııklarını doğrulamaktadır. Yapılan çalışmada tane veriminin yanında kalite açısından yüksek performans gösteren genotipleri belirlemek amacıyla genotipler, bin tane ağırı̆̆ı (g), protein oranı (\%) ve Zeleny sedimentasyon $(\mathrm{ml})$ bakımından değerlendirilmiş, 2 çevreye ait ortalama değerler ile 'LSD' test grupları Çizelge 3'de verilmiştir. 
Yakışır ve ark. "Ileri Kademe Bazı Ekmeklik Buğday (Triticum aestivum L.) Genotiplerinin Yağışa Dayalı Şartlarda Tane Verimi ve Bazı Kalite Parametreleri Yönünden Değerlendirilmesi"

Çizelge 2. Farklı çevrelerde ekmeklik buğday genotiplerinin tane verimi ortalama değerleri (kg/da) Table 2. Grain yield (kg/da) averages of bread wheat genotypes on different environments

\begin{tabular}{|c|c|c|c|c|c|c|c|c|c|c|}
\hline Genotip & Konya & İ.Çumra & Gözlü & Koçaş & Karaman & İkizce & Malya & Eskişehir & Hamidiye & Ort. \\
\hline 1 & $295 a-d^{*}$ & 188cde & $200 b-f$ & 292 & 140 & 316a-f & 470 & 303 efg & $209 a$ & $268 a^{* *}$ \\
\hline 2 & 289a-e & $224 a b c$ & $227 a b c$ & 294 & 154 & $289 a-g$ & 335 & $373 a b c$ & $172 a b$ & $262 a b$ \\
\hline 3 & $319 a b$ & $246 a b$ & $171 c-h$ & 258 & 149 & $353 a b$ & 363 & $383 a b$ & $152 a-d$ & $265 a$ \\
\hline 4 & $272 b-f$ & $163 e$ & $157 e-h$ & 281 & 140 & $237 \mathrm{efg}$ & 337 & $316 c-g$ & 107b-e & $223 \mathrm{cde}$ \\
\hline 5 & $272 b-f$ & 191b-e & $212 a-e$ & 194 & 132 & $227 \mathrm{fg}$ & 323 & $308 d-g$ & $87 \mathrm{de}$ & 216de \\
\hline 6 & $319 a b$ & 172 cde & $148 \mathrm{fgh}$ & 378 & 108 & $255 c-g$ & 328 & $296 f g$ & $107 b-e$ & $235 b-e$ \\
\hline 7 & $320 a b$ & $164 \mathrm{e}$ & $243 a b$ & 199 & 112 & $281 b-g$ & 390 & 338a-f & $114 b-e$ & $240 a-d$ \\
\hline 8 & $289 a-e$ & $225 a b c$ & $215 a-d$ & 230 & 132 & $294 a-g$ & 412 & $364 a-e$ & $161 \mathrm{abc}$ & $258 a b$ \\
\hline 9 & $250 c-f$ & $155 e$ & 192b-f & 266 & 133 & $222 \mathrm{fg}$ & 420 & $301 \mathrm{efg}$ & 91cde & $225 \mathrm{cde}$ \\
\hline 10 & 234def & 198b-e & $185 c-g$ & 231 & 126 & 231efg & 435 & $319 b-g$ & 89de & $227 \mathrm{cde}$ \\
\hline 11 & 239def & $184 \mathrm{cde}$ & $168 d-h$ & 199 & 115 & $235 \mathrm{efg}$ & 313 & 348a-f & $97 \mathrm{cde}$ & 211de \\
\hline 12 & 233def & $223 a-d$ & $150 \mathrm{fgh}$ & 237 & 117 & $247 d-g$ & 395 & $396 a$ & $101 b-e$ & 233be \\
\hline 13 & $217 \mathrm{fg}$ & $180 \mathrm{cde}$ & $147 \mathrm{fgh}$ & 242 & 121 & $199 \mathrm{~g}$ & 415 & $337 a-f$ & $101 \mathrm{~b}-\mathrm{e}$ & 218de \\
\hline 14 & $155 \mathrm{~g}$ & 199b-e & 113hı & 235 & 91 & $227 \mathrm{fg}$ & 414 & $327 b-g$ & $95 \mathrm{cde}$ & $207 e$ \\
\hline 15 & $325 a b$ & $269 a$ & $201 b-f$ & 282 & 125 & $281 \mathrm{bg}$ & 461 & $374 a b c$ & $109 b-e$ & $270 a$ \\
\hline 16 & 222efg & $150 \mathrm{e}$ & 133gh & 215 & 90 & $382 a$ & 382 & $344 a-f$ & $107 b-e$ & $225 \mathrm{cde}$ \\
\hline 17 & $225 \mathrm{ef}$ & $143 e$ & ו70 & 209 & 82 & $240 d-g$ & 271 & $228 \mathrm{~h}$ & $78 e$ & $172 f$ \\
\hline 18 & $309 a b c$ & $167 e$ & $165 d-h$ & 226 & 121 & $347 a b c$ & 445 & $372 a-d$ & $112 b-e$ & 252abc \\
\hline 19 & $276 a-f$ & $146 e$ & $186 c-g$ & 212 & 122 & $337 a-d$ & 352 & $268 \mathrm{gh}$ & $81 \mathrm{de}$ & 220de \\
\hline 20 & $341 a$ & $177 \mathrm{cde}$ & $266 a$ & 263 & 144 & $327 a-e$ & 399 & $346 a-f$ & $108 b-e$ & $263 a b$ \\
\hline Ort. & $270 c^{* *}$ & $188 d$ & $178 d$ & $247 c$ & 123 e & $276 c$ & 383 a & $332 b$ & $114 \mathrm{e}$ & 235 \\
\hline $\mathrm{DK}_{(\%)}$ & 17 & 21 & 22 & 43 & 28 & 24 & 26 & 13 & 44 & 28 \\
\hline
\end{tabular}

Aynı harflerle gösterilen ortalamalar arasındaki farklııklar *\%5,** \%1 önem seviyelerini göstermektedir.

Differences between averages shown with same letters are indicated using * for $\% 5$ and ${ }^{* *}$ for $\% 1$ significance levels.

Bin tane ağırı̆̆ı ekmeklik buğdayda tane verimini etkileyen önemli özelliklerden biri olmakla birlikte un randımanını etkilemesinden dolayı sanayiciler tarafından da önem verilen bir kalite unsurudur. Yapılan araştırma da bin tane ağırlığı bakımından çevreler istatistiki olarak önemsiz, genotipler $P<0.01$, çevre $x$ genotip interaksiyonu ise $P<0.05$ seviyesinde önemli olarak tespit edilmiştir. Bin tane ağırlıkları çevreler bakımından değerlendirildiğinde; en yüksek değer Konya $(34.0 \mathrm{~g})$, en düşük ise İçeriçumra (32.6 g) çevrelerinde alınmıştır. Genotipler bin tane ağırlığı bakımından değerlendirildiğinde deneme ortalaması $33.0 \mathrm{~g}$, standart çeşit ortalaması $33.2 \mathrm{~g}$ olarak belirlenmiş olup, en yüksek bin tane ağırlığı değeri $38.23 \mathrm{~g}$ ile hat16, en düşük ise $27.4 \mathrm{~g}$ ile hat11 genotiplerinden elde edilmiştir. Genotip × çevre interaksiyonu bakımından ise, en yüksek değer Konya'da hat8 (40.6 g) ve en düşük İçeriçumra'da hat11 (26.9 g) genotiplerinden elde edilmiştir (Çizelge 3). Bin tane ağırlığını Aktaş ve ark. (2011) 28.9-40.8 g olarak bildirirken, Naneli ve ark. (2015) 27.3-47 g arasında olduğunu belirtmişlerdir. Ancak araştırmamızda sözü geçen her iki araştırıcının da bildirdiği üst bin dane değerlerine ulaşılamamıştır.

Değişik araştırıcılar tarafından protein oranları, \%12.3-15.2 (Aydoğan ve ark. 2013); \%11.54-13.14 (Yağdı, 2004) gibi çeşide ve çevre koşullarına göre değişmekte olduğu bildirilmiştir (Kendal ve Doğan 2013). Bizim bulgularımızda benzer şekilde olup en yüksek Konya'dan (\%14.63), en düşük değer ise İçeriçumra'dan (\%12.72) alınmıştır. Deneme ortalaması \%13.67, standart çeşit ortalaması \%13.57 olarak belirlenmiştir. Genotipler bakımından en yüksek protein oranı $\% 14.80$ ile hat13'den elde edilirken en düşük \%12.26 ile hat 19 'dan elde edilmiştir. Çevre x genotip interaksiyonu bakımından ise en yüksek protein oranı Konya'da hat13 (\%16.68), en düşük ise İçeriçumra'da hat8 (\%11.57) genotiplerinde belirlenmiştir (Çizelge 3 ). Tosun ve ark. (1997) protein oranının kalıtımının oldukça karmaşık olduğunu ve çevresel varyasyonun fazla olması nedeniyle beklenen sonuçların ortaya çıkmadığını bildirmişlerdir.

$\mathrm{Bu}$ nedenle çalışmada protein oraları arasındaki farklılıklar, büyük oranda yetiştirme sezonunda gerçekleşen çevre koşulları ile açıklanabilir. 

Quality Traits under Rainfed Conditions"

Çizelge 3. Farklı çevrelerde ekmeklik buğday genotiplerinin bazı kalite parametreleri Table 3. Quality parameters and averages of bread wheat genotypes on different environments

\begin{tabular}{|c|c|c|c|c|c|c|c|c|c|}
\hline \multirow{2}{*}{ Genotip } & \multicolumn{3}{|c|}{ Bin Tane Ağırlığı (g) } & \multicolumn{4}{|c|}{ Protein Oranı (\%) } & \multicolumn{2}{|c|}{$\begin{array}{l}\text { Zeleny Sedimentasyon } \\
(\mathrm{ml})\end{array}$} \\
\hline & Konya* & İ.Çumra & Ort. ** & Konya** & İ.Çumra & Ort. ** & Konya** & İ.Çumra & Ort. ** \\
\hline 1 & $32.9 \mathrm{efg}$ & $32.1 \mathrm{~b}-\mathrm{f}$ & $32.5 e-h$ & $13.89 \mathrm{e}-\mathrm{h}$ & $12.54 b-h$ & $13.21 \mathrm{def}$ & 41.0hı & 34.5 I & $37.75 \mathrm{~h}$ \\
\hline 2 & $32.9 \mathrm{efg}$ & $30.2 d-h$ & $31.6 \mathrm{gh}$ & $14.42 \mathrm{~d}-\mathrm{g}$ & $12.81 \mathrm{~b}-\mathrm{f}$ & $13.62 b-f$ & 39.51 & 32.51 & $36.00 \mathrm{~h}$ \\
\hline 3 & $34.9 c-f$ & $33 b-f$ & $33.9 \mathrm{~d}-\mathrm{g}$ & 14.97b-f & $12.26 \mathrm{~d}-\mathrm{h}$ & $13.62 b-f$ & $51.5 \mathrm{cde}$ & $42.5 \mathrm{fg}$ & $47.00 \mathrm{ef}$ \\
\hline 4 & $32.3 \mathrm{efg}$ & $31.0 \mathrm{c}-\mathrm{h}$ & $31.5 \mathrm{ghı}$ & $15.03 b-f$ & $13.28 \mathrm{a}-\mathrm{d}$ & $14.15 a-c$ & 47.0efg & $52.5 \mathrm{bc}$ & $49.75 c-e$ \\
\hline 5 & $35.2 \mathrm{be}$ & $34.7 \mathrm{bc}$ & $34.9 \mathrm{bcd}$ & $14.59 \mathrm{c}-\mathrm{g}$ & $13.54 \mathrm{ab}$ & $14.06 a-d$ & $34.0 \mathrm{j}$ & $50.5 \mathrm{bcd}$ & $42.25 \mathrm{~g}$ \\
\hline 6 & $35.9 \mathrm{bcd}$ & $33.7 \mathrm{~b}-\mathrm{e}$ & $34.8 \mathrm{~b}-\mathrm{e}$ & 13.32gh & $12.21 \mathrm{e}-\mathrm{h}$ & $12.76 \mathrm{fg}$ & $56.5 a b$ & 46.0ef & $51.25 \mathrm{~cd}$ \\
\hline 7 & $37.4 \mathrm{bc}$ & $35.9 a b$ & $36.6 a b$ & $14.70 \mathrm{c}-\mathrm{g}$ & $14.12 a$ & $14.41 \mathrm{ab}$ & $53.0 \mathrm{bcd}$ & $51.5 \mathrm{bc}$ & $52.25 \mathrm{bc}$ \\
\hline 8 & $40.6 a$ & $32.1 b-f$ & $36.3 a b c$ & $14.53 \mathrm{~d}-\mathrm{g}$ & $11.57 \mathrm{~h}$ & $13.05 \mathrm{fg}$ & $45.5 \mathrm{fgh}$ & $36.5 \mathrm{~h}$ । & $41.00 \mathrm{~g}$ \\
\hline 9 & $31.7 \mathrm{~g}$ & $29.8 e-h$ & $30.7 \mathrm{hı}$ & $15.25 a-e$ & $13.03 b-e$ & $14.14 a-c$ & $57.0 a b$ & $41.0 \mathrm{~g}$ & 49.00de \\
\hline 10 & $30.9 \mathrm{gh}$ & $32.8 b-f$ & $31.8 f-1$ & $16.05 a-c$ & $11.97 \mathrm{fgh}$ & $14.01 \mathrm{a}-\mathrm{e}$ & $51.5 \mathrm{cde}$ & $57.5 a$ & $54.50 \mathrm{ab}$ \\
\hline 11 & 28.01 & $26.9 \mathrm{~h}$ & $27.4 \mathrm{j}$ & $15.09 b-f$ & 13.14a-e & $14.11 \mathrm{a}-\mathrm{c}$ & $44.0 \mathrm{gh}$ & $53.5 a b$ & $48.75 \mathrm{de}$ \\
\hline 12 & $35.5 \mathrm{~b}-\mathrm{e}$ & $35.6 a b$ & $35.5 \mathrm{bcd}$ & $15.47 a-d$ & $12.69 b-f$ & $14.08 \mathrm{a}-\mathrm{d}$ & $59.0 a$ & $41.0 \mathrm{~g}$ & $50.00 c-e$ \\
\hline 13 & $33.2 \mathrm{~d}-\mathrm{g}$ & $33.9 \mathrm{bcd}$ & $33.5 \mathrm{~d}-\mathrm{g}$ & $16.68 a$ & $12.92 b-f$ & $14.80 \mathrm{a}$ & $59.0 a$ & $54.5 a b$ & $56.75 a$ \\
\hline 14 & $28.2 \mathrm{hl}$ & $31.6 \mathrm{c}-\mathrm{g}$ & 29.91 & $16.33 a b$ & 13.13a-e & $14.73 a$ & $34.5 \mathrm{j}$ & $35.0 \mathrm{~h}$ । & $34.75 \mathrm{~h}$ \\
\hline 15 & $32.8 \mathrm{efg}$ & $29.3 \mathrm{fgh}$ & $31.0 \mathrm{~h}$ I & $13.63 f g h$ & $12.65 \mathrm{~b}-\mathrm{g}$ & $13.14 \mathrm{ef}$ & $54.0 \mathrm{bc}$ & $48.5 \mathrm{cde}$ & $51.25 \mathrm{~cd}$ \\
\hline 16 & $37.7 \mathrm{bc}$ & $38.8 a$ & $38.2 a$ & 15.23a-e & 13.09a-e & $14.16 a-c$ & 49.0def & $36.5 \mathrm{~h}$ । & $42.75 \mathrm{~g}$ \\
\hline 17 & $33.3 \mathrm{~d}-\mathrm{g}$ & $28.0 \mathrm{gh}$ & $30.7 \mathrm{hl}$ & $13.45 \mathrm{gh}$ & $13.36 \mathrm{a}-\mathrm{c}$ & $13.40 c-f$ & $57.0 \mathrm{ab}$ & $57.5 a$ & $57.25 a$ \\
\hline 18 & 38.0ab & $36.0 \mathrm{ab}$ & $37.0 \mathrm{ab}$ & 13.31gh & $12.31 \mathrm{c}-\mathrm{h}$ & $12.81 \mathrm{fg}$ & 48.0efg & $47.0 \mathrm{de}$ & $47.50 \mathrm{e}$ \\
\hline 19 & $34.9 c-f$ & $33.4 \mathrm{~b}-\mathrm{e}$ & $34.2 \mathrm{c}-\mathrm{f}$ & $12.90 \mathrm{~h}$ & 11.62gh & $12.26 \mathrm{~g}$ & 47.0efg & $41.0 \mathrm{~g}$ & $44.00 \mathrm{fg}$ \\
\hline 20 & $33.4 \mathrm{~d}-\mathrm{g}$ & $34.3 \mathrm{bc}$ & $33.8 \mathrm{~d}-\mathrm{g}$ & 13.69fgh & $12.10 \mathrm{e}-\mathrm{h}$ & $12.90 \mathrm{fg}$ & $56.0 \mathrm{abc}$ & $39.0 \mathrm{gh}$ & $47.50 \mathrm{e}$ \\
\hline Ort. & $34.0^{\text {öd }}$ & 32.6 & 33.3 & $14.63 a^{*}$ & $12.72 \mathrm{~b}$ & 13.67 & $49.2^{\text {od }}$ & 44.9 & 47.00 \\
\hline $\mathrm{DK}_{(\%)}$ & 4 & 6 & 5 & 5 & 4 & 5 & 5 & 5 & 5 \\
\hline
\end{tabular}

Aynı harflerle gösterilen ortalamalar arasındaki farklııklar *\%5, $\%$ \% 1 önem seviyelerini göstermektedir.

Differences between averages shown with same letters are indicated using * for $\% 5$ and ${ }^{* *}$ for $\% 1$ significance levels.

Bazı araştırıcılar tarafından (Erekul 2006; Şahin ve ark. 2013; Aydoğan ve ark. 2013) yapılan çalışmalarda Zeleny sedimentasyon değerlerinin 16.3-62.5 ml arasında değiştiği bildirilmiştir. $\mathrm{Bu}$ çalışmada da Zeleny sedimentasyon değerleri yukarıda belirtilen sınırlar arasında olup, en yüksek değer Konya'dan (49.2 ml), en düşük İçeriçumra'dan $(44.9 \mathrm{ml})$ alınmıştır. Deneme ortalaması $47 \mathrm{ml}$ olurken standart çeşit ortalaması $44 \mathrm{ml}$ olarak belirlenmiştir. Zeleny sedimentasyon bakımından genotipler içerisinde en yüksek değer $57.25 \mathrm{ml}$ ile hat17'den elde edilirken en düşük değer $34.75 \mathrm{ml}$ ile hat14'den elde edilmiştir. Çevre $\times$ genotip interaksiyonu bakımından ise en yüksek değer Konya'da hat12 ve hat13 (her ikisi de; $59.0 \mathrm{ml}$ ), en düşük İçeriçumra'da Gerek 79 (32.5 ml) genotiplerinden elde edilmiştir (Çizelge 3). Atlı ve Koçak (2003) Zeleny sedimentasyon değerinin kalıtımın etkisi altında olduğuna ve farklılıkların daha çok genotipe bağlı olduğuna dikkat çekmişlerdir.

\section{Sonuç}

Yapılan çalışma sonucunda, genotipler arasında incelenen karakterler açısından önemli farklılıklar elde edilmiştir. Hat15, hat20, hat8 ile Bayraktar 2000, Karahan 99 ve Gerek 79 çeşitleri tane verimi bakımından diğer hat ve çeşitlere göre yüksek performans göstermişlerdir (Çizelge 2). Bin tane ağırlığı, protein oranı ve Zeleny sedimentasyon gibi kalite özellikleri bakımından; bin tane ağırlığında (g) hat16, hat18, hat7, hat8, hat12; protein oranında (\%) hat13, hat14, hat7, hat16 ve Tosunbey çeşidi; Zeleny sedimentasyon ( $\mathrm{ml}$ ) açısından hat17, hat13, hat10, hat7, hat15 ve Eraybey çeşidi öne çıkmışlardır (Çizelge 3).

Tane verimi ve ele alınan kalite parametreleri açısından yapılan değerlendirmede, kontrol çeşitler ve diğer hatlardan daha üstün performansa sahip hat 15 seçilmiş ve çeşit adayı olarak Tohumluk Tescil ve Sertifikasyon Merkez Müdürlüğüne başvurusu yapılmıştır. 
Yakışır ve ark. "Illeri Kademe Bazı Ekmeklik Buğday (Triticum aestivum L.) Genotiplerinin Yağışa Dayalı Şartlarda Tane Verimi ve Bazı Kalite Parametreleri Yönünden Değerlendirilmesi"

\section{Kaynaklar}

Aktaş H., Kılıç H., Kendal E., Tekdal S., Kahraman M. ve Altıkat A., 2011. Diyarbakır Koşullarında Bazı Ekmeklik Buğday (Triticum aestivum L.) Genotiplerinin Verim ve Kalite Bakımından Değerlendirilmesi. Uluslararası Katılımlı I. Ali Numan Kıraç Tarım Kongresi ve Fuarı, 27-30 Nisan 2011, Eskişehir, 2273-2283

Anonim, 2000. Approved Methods of the American Associaation of Cereal Chemist, USA

Anonim, 2009. Approved Methodologies. www.leco.com/resources/approved_methods.

Anonim, 2014. Türkiye İstatistik Kurumu

Atlı A. ve Koçak N., 2003. Islah programlarında ekmeklik buğday kalitesinin farklı sedimentasyon testleri ile tahmini. Harran Üni. Ziraat Fak. Dergisi, 8(2): 51-57

Aydoğan S., Göçmen Akçacık A., Şahin M., Önmez H., Demir B. ve Yakışır E., 2013. Ekmeklik buğday çeşitlerinde fizikokimyasal ve reolojik özelliklerin belirlenmesi. Tarla Bitkileri Merkez Araştırma Enstitüsü Dergisi, 22(2): 74-85

Çetin Ö., Uygan D., Boyacı H. ve Öğretir K., 1999. Kışıı Buğdayda Sulama-Azot ve Bazı Önemli İklim Özellikleri Arasındaki İlişkiler. 3. Tarla Bitkileri Kongresi, 15-20 Kasım 1999, Adana, Cilt: 1, 151-156

Kendal E. ve Doğan Y., 2013. Ekmeklik buğday (Triticum aestivum L.) genotiplerinin tane verimi ve bazı kalite özelliklerinin belirlenmesi. GOÜ Ziraat Fak. Dergisi, 29(1) :113-121

Kün E., Avcı M., Uzunlu V. ve Zencirci N., 1995. Serin İklim Tahılları Tüketim Projeksiyonları ve Üretim Hedefleri. TMMOB Ziraat Mühendisleri Odası, 4. Türkiye Ziraat Mühendisleri Teknik Kongresi. 9-13 Ocak 1995, Ankara, 417-429
Mut Z., Aydın N., Özcan H. ve Bayramoğlu H.O., 2005. Orta karadeniz bölgesinde ekmeklik buğday (Triticum aestivum L.) genotiplerinin verim ve bazı kalite özelliklerinin belirlenmesi. GOP Üni. Ziraat Fak. Dergisi, 22(2): 85-93

Naneli I., Sakin M.A. ve Kıral A.S., 2015. Tokatkazova şartlarında bazı ekmeklik buğday (Triticum aestivum L.) çeşitlerinin verim ve kalite özelliklerinin belirlenmesi. GOP Üni. Ziraat Fak. Dergisi, 32(1): 91-103

Roth G.W., Marshall H.G., Hatley O.E. and Hill R.R., 1984. Effect of management practices on grain yield, test weight, and lodging of soft red winter wheat. Agronomy Journal, 76: 379-383

Sade B., 1997. Tahıl Islahı Buğday ve Mısır. Selçuk Üni. Ziraat Fak. Yay.: 31, Konya

Şahin M., Aydoğan S., Göçmen Akçacık A., Demir B., Önmez H., Taner S. ve Yakışır E., 2013. Orta Anadolu Bölgesinde Ekimi Yapılan Bazı Ekmeklik Buğday (Triticum aestivum L.) Genotiplerinin Kuru ve Sulu Koşullardaki Verim ve Kalite Özelliklerinin Karşılaştırılması. 10. Tarla Bitkileri Kongresi, 11-13 Eylül 2013, Konya, 670-676

Tosun F., Demir M., Yüce İ. ve Sever S., 1997. Buğdayda Proteinin Kalıtımı. 2. Tarla Bitkileri Kongresi, 22-25 Eylül 1997, Samsun, 61-65

Yağdı K., 2004. Bursa koşullarında geliştirilen ekmeklik buğday (Triticum aestivum L.) hatlarının bazı kalite özelliklerinin araştırılması. Uludağ Üni. Ziraat Fak. Dergisi, 18(1): 11-23 